\title{
The lichen family Parmeliaceae in Poland. III. Parmelia serrana, new to Poland
}

\author{
Emilia Ossowska', Rafał Szymczyk², Adam Bohdan³, Martin Kukwa ${ }^{*}$ \\ ${ }^{1}$ Department of Plant Taxonomy and Nature Conservation, University of Gdańsk, Wita Stwosza 59, 80-308 Gdańsk, Poland \\ ${ }^{2}$ EKOPROJEKT Environmental Survey Laboratory, Nowica 24, 14-405 Wilczęta, Poland \\ ${ }^{3}$ Society Workshop for All Beings, Świętojańska 22/1, 15-082 Białystok, Poland
}

\section{Abstract}

Parmelia serrana A. Crespo, M.C. Molina \& D. Hawksw. is reported here for the first time from Poland. The species has been recorded from more than 20 localities and exclusively on the bark of trees. Its general distribution, habitat requirements, morphology, secondary chemistry are provided and the differences between this species and similar taxa, especially P. saxatilis and P. ernstiae, are discussed.

Keywords: parmelioid lichens; chemotaxonomy; Parmelia serrana; distribution

\section{Introduction}

The genus Parmelia Ach. occurs in the boreal-temperate Northern Hemisphere [1,2]. It is characterized by foliose thalli, which are loosely to closely adnate to the substrate. Upper surface is smooth to foveolate, grey to brown-grey or grey-green, occasionally pruinose, with protoplectenchymatous and non-pored epicortex and always with usually elongated pseudocyphellae. The lower surface is black and uniformly rhizinate up to the margins, with simple, branched or squarrose rhizines. Some species develop soredia, pustules or isidia as the vegetative propagules. Apothecia are rare, especially in the species, which reproduce by soredia or isidia, with brown or rarely blackish discs; ascospores are colorless, ellipsoidal to oval in shape [1-5]. All Parmelia species contain atranorin and chloroatranorin in the cortex, but a variety of secondary metabolites are present in the medulla, including lobaric, salazinic and protocetraric acids $[3,5]$.

Although Parmelia species are easily observed in the field and occur in a variety of habitats, up to the end of the last decade its taxonomy was based mainly on morphological characters and rarely on chemical characters for species identification. However, as it was proved recently, this approach masked the presence of species representing distinct phylogenetic clades with similar or identical morphology and chemistry (so-called cryptic or semi-cryptic species) [6-12]. The taxonomy of the genus Parmelia appears to be still far

\footnotetext{
* Corresponding author. Email: dokmak@ug.edu.pl
}

Handling Editor: Krzysztof Spalik from resolved as material from only a few regions has been investigated and the discovery of additional undescribed taxa is expected.

Previously in Poland, only six taxa have been reported: Parmelia discordans Nyl., P. ernstiae Feurer \& A.Thell, P. omphalodes (L.) Ach., P. saxatilis (L.) Ach., P. submontana Nádv. ex Hale and $P$. sulcata Taylor [13-18]. Two of these, the isidiate $P$. saxatilis and the sorediate $P$. sulcata, commonly reported from Poland, were recently shown to represent a group of cryptic or semi-cryptic species [8-11,19]. Therefore, their previously known distribution and frequency in Poland should be treated rather as potential and are in need of re-evaluation.

During the revision of the material previously referred to $P$. saxatilis, $P$. serrana, a recently recognized species previously not reported from Poland, was discovered. The aim of this article is to present the first records of this species in the country. The morphology, chemistry and general distribution of the species and discussion on allied taxa are provided. This paper is the third in the series dealing with lichens of the Parmeliaceae in Poland [20,21], and one of numerous designed to aid recognition of the country's lichen biota (e.g. [22-29]).

\section{Material and methods}

Herbarium material loaned from the following Polish herbaria: GPN, KRAM, KRAP, OLS, WA, WRSL, UGDA and herbarium of the Society Workshop for All Beings from Białystok (in the locality section as herb. SWAB) has been revised. 
Morphology was studied with a stereomicroscope and following characters were examined: color and structure of the upper surface (pruinose, not pruinose or dull), shape and development of lobes (elongated, broad, short, oval, imbricate or not), type of rhizines and their shape (simple, squarrose or branched), the abundance, shape (narrow or oval) and distribution (marginal, laminal) of pseudocyphellae, the abundance, shape and distribution on thallus of isidia. The secondary lichen compounds were studied with thin layer chromatography (TLC) in solvent A and C, according to Orange et al. [30]. The localities in Poland were mapped according to the ATPOL grid square system [31].

\section{Results and discussion}

Parmelia serrana A. Crespo, M.C. Molina \& D. Hawksw. in Molina et al., Lichenologist 36(1): 48 (2004).

ICONOGRAPHY. Molina et al. [9], Thell et al. [5].

MORPHOLOGICAL CHARACTERS. Thalli adnate to loosely adnate, $3-7 \mathrm{~cm}$ in diameter; lobes sometimes overlapping, rounded to sublinear, up to 2-4 mm wide; upper surface pale greenish-grey to whitish-grey, shiny mainly towards the margins, sometimes dull and reticulately cracked, epruinose (sometimes, few lobe tips have faint pruina); pseudocyphellae linear or irregular in shape; isidia simple, cylindrical or branched, up to $0.2-0.8 \mathrm{~mm}$ tall and $0.05-0.1 \mathrm{~mm}$ wide, laminal and marginal, in well developed specimens densely covering central parts of the thalli; lower surface black, with long, simple or branched (but not squarrose) rhizines, up to $0.2-1 \mathrm{~mm}$ long; apothecia rare in Polish material; disc brown and concave; ascospores broadly ellipsoidal, $16-18 \times 11.5-13 \mu \mathrm{m}$.

SECONDARY CHEMISTRY. The species produces atranorin (moderate amounts), salazinic acid (major), consalazinic acid (minor), often protocetraric acid (trace amounts only) and fatty acids: lichesterinic and protolichesterinic acids. The chemistry agrees with that reported by Molina et al. [9] and Thell et al. [5,11].

NOTES. Parmelia serrana is morphologically and chemically very similar to $P$. saxatilis and apparently for many years considered as a chemical variant of the latter species [1]. However, recent molecular data supported the recognition of P. serrana as a distinct taxon [9]. Both taxa are very similar, but they can be easily separated by their chemistry since $P$. serrana produces fatty acids instead of lobaric acid, which is present in P. saxatilis. There are also some morphological differences $[5,9,11]$, which are summarized in Tab. 1 .

Parmelia serrana can also be confused with P. ernstiae, but the thallus of the latter is strongly pruinose and, in addition to all substances produced by $P$. serrana, $P$. ernstiae contains lobaric acid $[5,9,11,32]$. All differences are presented in Tab. 1.

Recently, another species similar to P. serrana, $P$. mayi Divakar, A. Crespo, M.C. Molina, has been described from North America. The differences between both species refer mainly to their chemistry. Parmelia mayi produces almost the same set of secondary metabolites as $P$. serrana, but protocetraric acid is absent while alectorialic acid is present instead. Until now $P$. mayi is known only from high montane areas of northern Appalachian Mountains, North America [8].
Parmelia serrana can be confused with P. submontana, which produces granular to nearly isidioid soredia. However, the thallus lobes of P. submontana are elongated and little branched with down-rolled margins and the species lacks fatty acids (only atranorin and salazinic acid are present) $[3,5,15]$.

Other Parmelia species reported from Poland cannot be mistaken for $P$. serrana because $P$. discordans and $P$. omphalodes lack vegetative diaspores, while $P$. sulcata propagates through soredia $[3,5]$.

HABITAT REQUIREMENTS. Parmelia serrana grows on coniferous and deciduous trees and rarely on mossy rocks [3,5]. The Polish specimens are mostly epiphytic and have been collected predominantly from bark of deciduous trees (Betula spp., Alnus spp., Carpinus betulus, Fagus sylvatica, Fraxinus excelsior, Populus spp., Quercus spp., Salix spp., Tilia cordata) in forests or roadside alleys and only rarely (one specimen) on bark of Pinus sylvestris. One sample was also found on sand dunes.

DISTRIBUTION IN POLAND. The currently known distribution of Parmelia serrana in Poland is presented in Fig. 1. Thr species is distributed in both the northern and southern parts of the country, and is probably much more common, since $P$. saxatilis s.l., under which name the species was previously recorded, was not always documented with herbarium vouchers and therefore some published records cannot be verified.

GENERAL DISTRIBUTION. Parmelia serrana appears to be rather widely distributed. So far, it has been found in Europe (Austria, Germany, Finland, Russia, Spain, Sweden and Ukraine) $[5,8,9,11,16,33]$ and Africa (Canary Islands). It probably occurs in North America, since Hale [1] reported specimens of $P$. saxatilis s.l. without lobaric acid; however, this hypothesis needs to be confirmed and specimens studied by Hale must be re-examined.

\section{NUMBER OF SPECIMENS EXAMINED - 28.}

SELECTED SPECIMENS EXAMINED. Ac-37 - Mierzeja Helska Sandbar, $1 \mathrm{~km}$ from Władysławowo town, on Pinus sylvestris, 1986.07.10, B. Wojtyła (UGDA L-2899). Ac-43 -Wybrzeże Słowińskie Coast, Słowiński National Park, Mierzeja Łebska Split, forest section No. 8, on sand, 1996.09.08, W. Fałtynowicz (UGDA L-5061). Ac-56 - Pradolina Redy i Łeby Glacial Valley, Świetlino village, forest section No. 31, on bark of tree, 1972.07.27, T. Sulma (UGDA L-5851). Ac-76 - Pojezierze Kaszubskie Lakeland, Szczelina Lechicka Nature Reserve, on Alnus glutinosa, 2012.05.05, A. Kowalewska (UGDA). Ac-95 - Pojezierze Kaszubskie Lakeland, $1 \mathrm{~km}$ E of Klukowa Huta village, on Tilia cordata, 1994.06.16, W. Fałtynowicz (UGDA L-4375). Bc-08 - Pojezierze Kaszubskie Lakeland, Przywidz village, by Przywidz Lake, on Fagus sylvatica, 1985.10.25, W. Fałtynowicz (UGDA L-2581). Bc-25 - Pojezierze Kaszubskie Lakeland, by Sasnowicz Lake near Dziemiany village, on Betula pendula, 1986.07.25, J. Miądlikowska (UGDA L-3543). Bd-79 - Garb Lubawski, Wzgórza Dylewskie Landscape Park, near Wygoda village, roadside trees, on Betula pendula, 2003.08.23, R. Szymczyk (OLS L-339). Bf-03 - Pojezierze Ełckie Lakeland, Borki Nature Reserve, forest section No. 22, on Carpinus betulus, 2012.09.19, R. Szymczyk (OLS L-1284); ibid., forest section No. 15, on bark of tree, 2012.08.22, R. Szymczyk (OLS 
Tab. 1 Diagnostic characters of isidiate Parmelia species occurring in Poland.

\begin{tabular}{llll}
\hline Characters & P. serrana & P. ernstiae & P. saxatilis \\
\hline type of thallus & epruinose, rarely faint pruina at lobe tips & strongly pruinose & epruinose or partially pruinose \\
shape of lobes & broad and round, often overlapping & broad and round, not overlapping & sublinear, not overlapping \\
type of isidia & epruinose & pruinose & epruinose \\
atranorin & present & present & present \\
salazinic acid & present & present & present \\
lobaric acid & absent & present & present \\
lichesterinic and & present & present & absent \\
protolichesterinic acids & & & \\
\hline
\end{tabular}

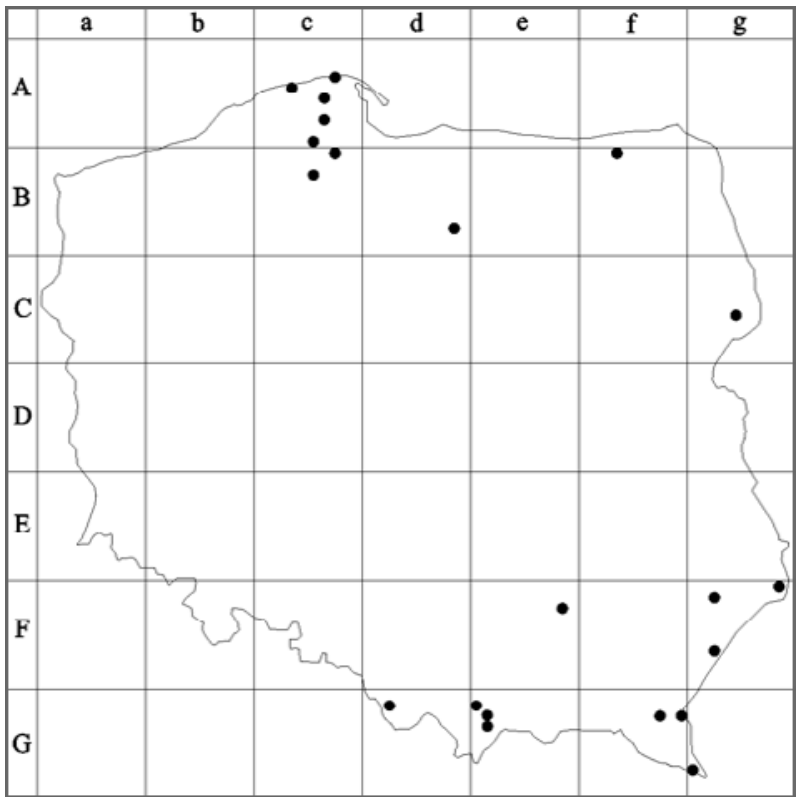

Fig. 1 Distribution of Parmelia serrana in Poland.

L-1243); Borki Nature Reserve, on Quercus sp., 1987.08.27, J. Zielińska (WA 28982). Cg-54 - Równina Bielska Plain, Białowieża Forest, Białowieża forest division, Zwierzyniec forest district, Natural Woodlands of Białowieża Forest Reserve, forest section No. 392A, wet alder forest, on Fraxinus

\section{Acknowledgments}

We are grateful to the Curators of herbaria for the loan of specimens and the reviewers for the constructive remarks. We thank also Professor Mark R.D. Seaward (Bradford) for checking the English. The research was supported by the Ministry of Science and Higher Education, project No. 2012/07/N/ NZ8/00061 granted to EO.

\section{Authors' contributions}

The following declarations about authors' contributions to the research have been made: field and herbarium research: EO, RS, AB, MK; determination of specimens: EO, RS, MK, chromatographic analyses: EO, RS; writing of the manuscript: $\mathrm{EO}, \mathrm{MK}, \mathrm{RS}, \mathrm{AB}$; preparation of the distribution map: $\mathrm{EO}, \mathrm{MK}$. excelsior, 2013.07.12, A. Bohdan (herb. SWAB); ibid., on branch of Carpinus betulus, 2013.07.12, A. Bohdan (herb. SWAB). Fe-28 - Niecka Połaniecka Basin, Przeczów Stara Wieś village, on Betula sp., 1990.09.04, J. Kiszka (KRAM L-60083). Fg-08 - Pogórze Przemyskie Foothills, Cisowa, forest section No. 30b, roadside, on Quercus sp., 1997.08.24, J. Kiszka (KRAM L-60081); road between Sanok to Przemyśl towns, on Salix sp., 1984.07.23, J. Kiszka \& J. Piórecki (KRAM L-60091). Fg-12 - Roztocze Środkowe, Hamernia, on old Quercus, 1986.06.08, J. Kiszka \& J. Piórecki (KRAM L-60092). Fg-62 - Płaskowyż Tarnogrodzki Plateau, S of Lubaczów town, Wielkie Oczy village, on Betula sp., 1984.07.24, J. Kiszka \& J. Piórecki (KRAM L-60094). Gd-12 - Beskid Śląski Mts, Dolina Białej Wisełki valley, Fojtula village, on Alnus sp., T. Sulma (UGDA L-5330). Ge-10 - Gorce Mts, Poręba Wielka village, alt. $550 \mathrm{~m}$, on bark of tree, 1993.11.23, P. Czarnota (GPN/1/94). Ge-21 - Gorce Mts, Gorce National Park, Turbacz Nature Reserve, below Czoło glade in Olszowy Potok valley, alt. $960 \mathrm{~m}$, on Abies alba, 1994.06.23, P. Czarnota (GPN/653/94). Ge-31 - Pieniny Mts, Kramnica village, on Salix sp., 1998.08.15, J. Kiszka \& J. Piórecki (KRAM L-64841). Gf-27 - Góry Słonne Mts, Rudenka village, on Salix sp., 1988.07.08, J. Kiszka \& J. Piórecki (KRAM L-60085). Gf-29 - Pogórze Przemyskie Foothills, Liskowate, on Populus tremula, 1987.09.30, J. Kiszka \& J. Piórecki (KRAM L-60080); ibid., on Salix sp., 1981.08.31, J. Kiszka \& J. Piórecki (KRAM L-60077). Gg-70 - Bieszczady Zachodnie Mts, Połonina Bukowska, near the road to Bukowska Przełęcz pass, on Alnus sp., 1998.08.05, J. Kiszka \& J. Piórecki (KRAM L-60097).

\section{References}

1. Hale ME. A monograph of the lichen genus Parmelia Acharius sensu stricto (Ascomycotina: Parmeliaceae). Smithson Contrib Bot. 1987;(66):1-55. http://dx.doi.org/10.5479/si.0081024X.66

2. Ferencova Z, Cubas P, Divakar PK, Molina MC, Crespo A. Notoparmelia, a new genus of Parmeliaceae (Ascomycota) based on overlooked reproductive anatomical features, phylogeny and distribution pattern. Lichenologist. 2014;46(1):51-67. http://dx.doi.org/10.1017/ S0024282913000649

3. Louwhoff SHJJ, Purvis OW, James PW. Parmelia Ach. (1803). In: Smith CW, Aptroot A, Cooppis BJ, Fletcher A, Gilbert OL, James 
PW, et al., editors. The lichens of Great Britain and Ireland. London: British Lichen Society; 2009. p. 651-654.

4. Crespo A, Kauff F, Divakar PK, del Prado R, Pérez-Ortega S, de Paz GA, et al. Phylogenetic generic classification of parmelioid lichens (Parmeliaceae, Ascomycota) based on molecular, morphological and chemical evidence. Taxon. 2010;59(6):1735-1753.

5. Thell A, Thor G, Ahti T. Parmelia Ach. In: Thell A, Moberg R, editors. Nordic lichen flora. Göteborg: Nordic Lichen Society; 2011. p. 83-90. (vol 4)

6. Crespo A, Pérez-Ortega S. Cryptic species and species pairs in lichens: a discussion on the relationship between molecular phylogenies and morphological characters. Jard Bot Madr. 2010;66(S1):71-81. http:// dx.doi.org/10.3989/ajbm.2225

7. VondráK J, Ríha P, Arup U, SøChting U. The taxonomy of the Caloplaca citrina group (Teloschistaceae) in the Black Sea region; with contributions to the cryptic species concept in lichenology. Lichenologist. 2009;41(6):571. http://dx.doi.org/10.1017/S0024282909008317

8. Molina MC, Del-Prado R, Divakar PK, Sánchez-Mata D, Crespo A. Another example of cryptic diversity in lichen-forming fungi: the new species Parmelia mayi (Ascomycota: Parmeliaceae). Org Divers Evol. 2011;11(5):331-342. http://dx.doi.org/10.1007/s13127-011-0060-4

9. Molina MC, Crespo A, Blanco O, Lumbsch HT, Hawksworth DL. Phylogenetic relationships and species concepts in Parmelia s.str. (Parmeliaceae) inferred from nuclear ITS rDNA and tubulin sequences. Lichenologist. 2004;36(1):37-54. http://dx.doi.org/10.1017/ S0024282904013933

10. Molina MC, Divakar PK, Millanes AM, SáNchez E, Del-Prado R, Hawksworth DL, et al. Parmelia sulcata (Ascomycota: Parmeliaceae), a sympatric monophyletic species complex. Lichenologist. 2011;43(6):585-601. http://dx.doi.org/10.1017/S0024282911000521

11. Thell A, Elix JA, Feuerer T, Hansen ES. Notes on the systematics, chemistry and distribution of European Parmelia and Punctelia species (lichenized ascomycetes). Sauteria. 2008;15:545-559.

12. Crespo A, Divakar PK, Hawksworth DL. Generic concepts in parmelioid lichens, and the phylogenetic value of characters used in their circumscription. Lichenologist. 2011;43(6):511-535. http://dx.doi. org/10.1017/S0024282911000570

13. Nowak J, Tobolewski Z. Porosty Polskie. Warsaw: Polish Scientific Publishers PWN; 1975.

14. Fałtynowicz W. The lichens, lichenicolous and allied fungi of Poland - an annotated checklist. Cracow: W. Szafer Institute of Botany, Polish Academy of Sciences; 2003.

15. Motiejūnaitė J, Kukwa M. Parmelia submontana in Lithuania and northern Poland. Graph Scr. 2003;14:62-64.

16. Hawksworth DL, Blanco O, Divakar PK, Ahti T, Crespo A. A first checklist of parmelioid and similar lichens in Europe and some adjacent territories, adopting revised generic circumscriptions and with indications of species distributions. Lichenologist. 2008;40(1):1-21. http://dx.doi.org/10.1017/S0024282908007329

17. Kukwa M, Łubek A, Szymczyk R, Zalewska A. Seven lichen species new to Poland. Mycotaxon. 2012;120(1):105-118. http://dx.doi. org/10.5248/120.105

18. Ossowska E, Kukwa M. Nowe stanowiska porostu Parmelia ernstiae Feuerer \& A. Thell w Polsce. Acta Bot Cassub. 2012;11:195-199.

19. Crespo A, Molina MC, Blanco O, Schroeter B, Sancho LG, Hawksworth DL. rDNA ITS and $\beta$-tubulin gene sequence analyses reveal two monophyletic groups within the cosmopolitan lichen Parmelia saxatilis. Mycol Res. 2002;106(7):788-795. http://dx.doi.org/10.1017/ S095375620200610X

20. Jabłońska A, Oset M, Kukwa M. The lichen family Parmeliaceae in Poland I. The genus Parmotrema. Acta Mycol. 2009;44:211-222.

21. Kukwa M, Pietnoczko M, Czyżewska K. The lichen family Parmeliaceae in Poland. II. The genus Cetrelia. Acta Soc Bot Pol. 2012;81(1):43-52. http://dx.doi.org/10.5586/asbp.2012.007

22. Kowalewska A, Kukwa M. Cladonia metacorallifera (lichenized Ascomycota, Cladoniaceae) new to Poland and additional record from Slovakia. Biol Bratisl. 2004;59:433-434.

23. Flakus A. Three species of lichenized Ascomycota new to Poland. Biol Bratisl. 2006;61(1):15-17. http://dx.doi.org/10.2478/ s11756-006-0003-2

24. Kukwa M, Kubiak D. Six sorediate crustose lichens new to Poland. Mycotaxon. 2007;102:155-164.

25. Syrek M, Kukwa M. Taxonomy of the lichen Cladonia rei and its status in Poland. Biol Bratisl. 2008;63(4):493-497. http://dx.doi.org/10.2478/ s11756-008-0092-1

26. Krzewicka B. The "Verrucaria fuscella group" in Poland with some nomenclatorial remarks. Acta Soc Bot Pol. 2009;78(3):229-234. http:// dx.doi.org/10.5586/asbp.2009.029

27. Kukwa M, Jabłońska A. New records of two crustose sorediate lichens from central Europe. Mycotaxon. 2009;107(1):375-381. http://dx.doi. org/10.5248/107.375

28. Kubiak D. Distribution and ecology of the lichen Fellhanera gyrophorica in the Pojezierze Olsztyńskie Lakeland and its status in Poland. Acta Soc Bot Pol. 2011;80(4):293-300. http://dx.doi.org/10.5586/ asbp. 2011.035

29. Śliwa L, Flakus A. Lecanora microloba, a new saxicolous species from Poland. Lichenologist. 2010;43(1):1-6. http://dx.doi.org/10.1017/ S0024282910000551

30. Orange A, James PW, White FJ. Microchemical methods for the identification of lichens. London: British Lichen Society; 2001.

31. Cieśliński S, Fałtynowicz W. Note from editors. In: Cieśliński S, Fałtynowicz W, editors. Atlas of the geographical distribution of lichens in Poland. Cracow: W. Szafer Institute of Botany, Polish Academy of Sciences; 1993. p. 7-8. (vol 1).

32. Feuerer T, Thell A. Parmelia ernstiae - a new macrolichen from Germany. Mitt Inst Allg Bot Hamb. 2002;30-32:49-60.

33. Hawksworth DL, Divakar PK, Crespo A, Ahti T. The checklist of parmelioid and similar lichens in Europe and some adjacent territories: additions and corrections. Lichenologist. 2011;43(6):639-645. http:// dx.doi.org/10.1017/S0024282911000454 